\title{
ANALISIS KESALAHAN SISWA SMK DALAM MEMECAHKAN MASALAH LITERASI MATEMATIS PADA MATERI BANGUN RUANG
}

\author{
Sopian Lukman ${ }^{1}$, Luvy Sylviana Zanthy ${ }^{2}$ \\ 1,2,3 IKIP Siliwangi, J1. Terusan Jenderal Sudirman, Cimahi, Jawa Barat, Indonesia \\ ${ }^{1}$ sopianlukman02@gmail.com, ${ }^{2}$ zanthy23@yahoo.com
}

Diterima: 27 Desember 2018; Disetujui: 6 Mei 2019

\begin{abstract}
This research was conducted with the aim of describing the mistakes made by students in solving the problem of mathematical literacy. The research method used is descriptive qualitative. Data obtained through written tests consisting of 4 questions about mathematical literacy skills obtained $58 \%$ of students were able to master the problem of mathematical literacy, so that $42 \%$ of students were unable to master the problem of mathematical literacy skills. The average score of students is 34.29 with the highest value of 50 and the lowest value is 16 of the total maximum value 55. From the results of the analysis carried out on student answers, there are several mistakes made by students when completing the problem, namely: not systematic; Wrong in using formulas; Many do not use units; Wrong in writing units; Unable to interpret questions; Wrong and conclude the results of the settlement; Not complete in completion.
\end{abstract}

Keywords: Error Analysis, Mathematical Literacy Skills

\begin{abstract}
Abstrak
Penelitian ini dilakukan dengan tujuan untuk menganalisis kesalahan siswa selama memecahkan masalah literasi matematis. Desain penelitian yang dipakai yaitu deskriptif kualitatif. Data diperoleh melalui tes tulis, dimana dari total 4 soal literasi matematis diperoleh $58 \%$ siswa mampu menguasai soal literasi matematis, sehingga diperoleh $42 \%$ siswa tidak bisa menguasai soal literasi matematis. Rata-rata nilai siswa yaitu 34,29 dengan nilai tertinggi 50 dan nilai terendahnya adalah 16 dari total nilai maksimalnya 55. Dari hasil analisis yang dilakukan terhadap jawaban siswa, terdapat beberapa kekeliruan yang dibuat siswa ketika memecahkan masalah tersebut yaitu: proses penyelesaian yang dilakukan tidak sistematis; salah dalam menggunakan rumus; banyak yang tidak menggunakan satuan; keliru dalam menuliskan satuan; tidak mampu mengiterpretasikan soal; keliru dan menyimpulkan hasil penyelesaian; tidak tuntas dalam penyelesaian.
\end{abstract}

Kata Kunci: Analisis Kesalahan, Kemampuan Literasi Matematis

How to cite: Lukman, S., \& Zanthy, L. S., (2019). Analisis Kesalahan Siswa SMK Dalam Memecahkan Masalah Literasi Matematis pada Materi Bangun Ruang. JPMI- Jurnal Pembelajaran Matematika Inovatif, 2 (3), 101-105.

\section{PENDAHULUAN}

Matematika ialah salah satu dari beberapa mata pelajaran di sekolah yang sangat penting serta erat kaitannya dengan aktivitas yang dilakukan semua individu. Pada setiap kegiatan yang dikerjakan seseorang sebenarnya sering mereka jumpai beragam permasalahan yang erat kaitannya dengan matematika dan membutuhkan matematika dalam proses menyelesaikannya. 
Untuk dapat menyelesaikan atau mengatasi setiap permasalahan yang berhubungan dengan matematika tersebut diperlukan beberapa kemampuan yaitu menganalisa, memberikan alasan, memberikan persepsi secara efisien, meringkas, mengatasi, dan menafsirkan setiap permasalahan dalam beragam konteks dan cara, atau bisa kita sebut sebagai kemampuan literasi matematis. Hal tersebut seirama dengan pandangan Cockroft (Abdurrahman, 2005:253) matematika sangatlah penting untuk diberikan pada setiap siswa, dikarenakan (1) sering dipergunakan dalam berbagai kehidupan, (2) seluruh bagian aspek dalam kehidupan membutuhkan kompetensi matematika yang sesuai, (3) melambangkan media koneksi yang kuat, kompak dan solid, (4) mampu berperan dalam menyediakan informasi dalam ragam model, (5) mengembangkan kompetensi berasumsi analitis, akurasi, dan pemahaman keruangan, dan (6) mempersembahkan kegembiraan terhadap upaya mengatasi permasalahan yang menantang.

Literasi matematis yakni kapasitas personal demi menyebutkan, mengoperasikan, dan menginterpretasikan matematika dalam beragam hal, literasi matematis mencakup penalaran matematis yang mempergunakan suatu konsep, langkah-langkah, fakta, serta alat matematika guna menggambarkan, mengasosiasikan, dan memperkirakan kejadian. Kemampuan literasi matematis sangat diperlukan dalam aktivitas keseharian dan untuk membuat suatu keputusan yang masuk akal dan diperlukan secara konstruktif, terlibat dan reflektif. Menurut Kusumah (Maryanti, 2012:16) Literasi matematis adalah suatu kecakapan siswa dalam merencanakan serangkaian persoalan, menyimpulkan, mengatasi beserta mengasosiasikan persoalan yang berbasis pada situasi tertentu. Pernyataan tersebut sesuai dengan yang dikatakan oleh Isnaini (Maryanti, 2012:16) yang memberikan definisi literasi selaku kompetensi siswa untuk memahami keadaan, konsepsi, kaidah, proses, beserta pemecahan masalah.

PISA (Programme Internationale for Student Assesment) yaitu badan studi internassional yang salah satu programnya adalah menilai kemampuan literasi matematika, IPA, dan bahasa yang dilaksanakan setiap 3 tahun sekali dan dirancang untuk siswa usia 15 tahun pada setiap negara. Siswa yang berumur 15 tahun jelas belum mampu banyak belajar, namun mereka patut mengantongi prinsip yang kokoh dalam menghadapi kehidupan mendatang. Prinsip tersebut berupa pemahaman proses dan prinsip-prinsip khususnya matematika, serta menggunakannya dalam dalam situasi yang beragam. Berdasarkan hasil PISA 2015 kemampuan literasi siswa masih bisa dibilang rendah. Ada beberapa sampel yang menyebakan kurangnya kemampuan literasi matematis siswa disebabkan oleh seringnya siswa melakukan kesalahan dalam proses menyelesaikan suatu permasalahan matematika. Kondisi tersebut seirama dengan pandangan Mahdiansyah \& Rahmawat (2014) yang mengatakan bahwa ada beberapa faktor yang mempengaruhi pencapaian literasi matematis di Indonesia diantaranya adalah faktor personal, faktor instruksional dan faktor lingkungan.

Dalam suatu pembelajaran matematika, seringkali kita menemukan siswa yang memahami suatu konsep terhadap materi yang sedang dipelajari, akan tetapi salah dalam mengimplementasikan rumus yang akan digunakan untuk memecahkan permasalahan matematika. Adapun siswa yang tidak memahami konsep sama sekali pada saat pembelajaran berlangsung. Tetapi pada saat memecahkan permasalahan matematika, siswa tersebut mampu memperoleh jawaban yang tepat karena menggunakan unsur logika dalam dirinya. Begitu juga dengan kesalahan siswa yang kerap timbul adalah karena salah dalam proses menghitung. Kondisi tersebut seirama dengan Sahriah (2012) yang mengatakan bahwa siswa mampu memahami konsep dan prosedur terhadap materi yang sedang dipelajari akan tetapi siswa acapkali tidak teliti dengan proses perhitungan sehingga menyebabkan adanya kekeliruan pada proses menyelesaikan permasalahan matematika. 
Siswa SMK masih banyak yang mengalami kesulitan dalam pembelajaran matematika, salah satunya siswa seringkali merasa kesulitan saat memahami materi, sehingga menyebabkan adanya kesalahan dalam menyelesaikan soal. Hal tersebut dapat mempengaruhi hasil belajar siswa, sehingga diperlukan analisis terhadap kesalahan yang telah dilakukan oleh siswa. Menurut (Poerwadarminta, 2006), salah yaitu tidak sebagaimana mestinya, tidak benar, tidak betul atau keliru. Sedangkan kesalahan berarti kekeliruan, penyimpangan dari yang seharusnya, atau suatu perbuatan yang salah. Berdasarkan uraian tersebut, maka dilakukan penelitian pendidikan dengan judul "Analisis Kesalahan Siswa SMK dalam Menyelesaikan Soal Literasi Matematis pada Materi Bangun Ruang”.

\section{METODE}

Jenis Desain penelitian yang dipakai yaitu deskriptif kualitatif dengan tujuan untuk mendeskripsikan kekeliruan yang dibuat siswa dalam memecahkan permasalahan bangun ruang dilihat dari tingkat kemampuan literasi matematis siswa SMK. Metode deskriptif menurut (Nawawi, 2012) merupakan cara memecahkan suatu permasalahan yang dilakukan dengan mendskripsikan keadaan subyek/obyek penelitian berdasarkan dengan fakta yang ada. Data penelitian ini didapatkan melalui tes tulis yang terdiri dari 4 soal kemampuan literasi matematis. Adapun literasi matematis yang digunakan pada penelitian ini mengacu pada beberapa indikator berikut: (1) Literasi matematis level 2, siswa dapat menafsirkan permasalahan dan meemcahkannya dengan menggunakan rumus, (2) Literasi matematis level 3, siswa dapat melakukan tahapan dengan baik dalam memecahkan permasalahan serta mampu menentukan strategi pemecahan masalah yang sederhana, dan (3) Literasi matematis level 4, siswa dapat bekerja efektif dengan model dan dapat memilih serta mengintegrasikan representasi yang berbeda, kemudian menghubungkannya dengan dunia nyata. Sampel dari penelitian ini adalah 31 siswa kelas XII SMK Negeri di kota Cimahi.

\section{HASIL DAN PEMBAHASAN}

\section{Hasil}

Berdasarkan Dari hasil penelitian yang dilakukan diperoleh data rata-rata nilai siswa, standar deviasi, nilai tertinggi dan terendah seperti berikut :

Tabel 1. Rata-Rata, Standar Deviasi, Nilai Tertinggi dan Nilai Terendah

\begin{tabular}{ll}
\hline Rata-Rata & 34,29032 \\
\hline Standar Deviasi & 10,19803 \\
\hline Nilai Tertinggi & 50 \\
\hline Nilai Terendah & 16 \\
\hline
\end{tabular}

Berdasarkan Tabel 1, rata-rata nilai siswa dari 31 siswa adalah 34,29, memiliki standar deviasi 10,19 dimana nilai tertinggi yang didapat siswa adalah 50 dan nilai terendah yang diperoleh adalah 16 dari nilai maksimalnya adalah 55. Adapun penguasaan soal dari 31 siswa dalam memecahkan permasalahan literasi nomor 1 diperoleh 52\%, untuk nomor 2 hanya $68 \%$, untuk nomor 3 hanya 55\%, dan untuk nomor 4 hanya $61 \%$ saja. Ada banyak sebab kesalahan tersebut dapat terjadi. Penyebab tersebut yaitu kesalahan dalam memahami suatu konsep yang berlaku, kesalahan mengubah/ menerjemahkan bahasa/ ungkapan matematik, kesalahan dalam 
memahami perhitungan, dan terkecoh dengan soal tanpa melihat tujuan dari soal serta tidak mengetahui solusi menyelesaikannya.

Lerner (Abdurrahman, 1999) menyebutkan terkait kesalahan-kesalahan yang umum terjadi dan dilakukan oleh anak pada saat mengerjakan soal matematika, yaitu kurangnya dari pengetahuan tentang simbol-simbol matematika, kurangnya pemahaman tentang nilai tempat, penggunaan prosedur yanng keliru, salah perhitungan, serta tulisan yang tidak terbaca dengan baik sehingga membuat anak melakukan kekeliruan. Adapun menurut Azia (2004) dalam penelitiannya memperoleh hasil bahwa kesalahan yang paling sering dilakukan oleh siswa adalah kesalahan konsepsi, kesalahan perencanaan, dan kesalahan memahami soal.

\section{Pembahasan}

Berdasarkan tes yang dilakukan di kelas XII SMK Negeri di kota Cimahi diperoleh beberapa gambaran kesalahan siswa pada saat memecahkan permasalahan literasi matematis. Berikut adalah beberapa sampel kesalahan-kesalahan siswa dalam penyelesaian setiap soalnya.

\section{Jawaban siswa pada soal Nomor 1}

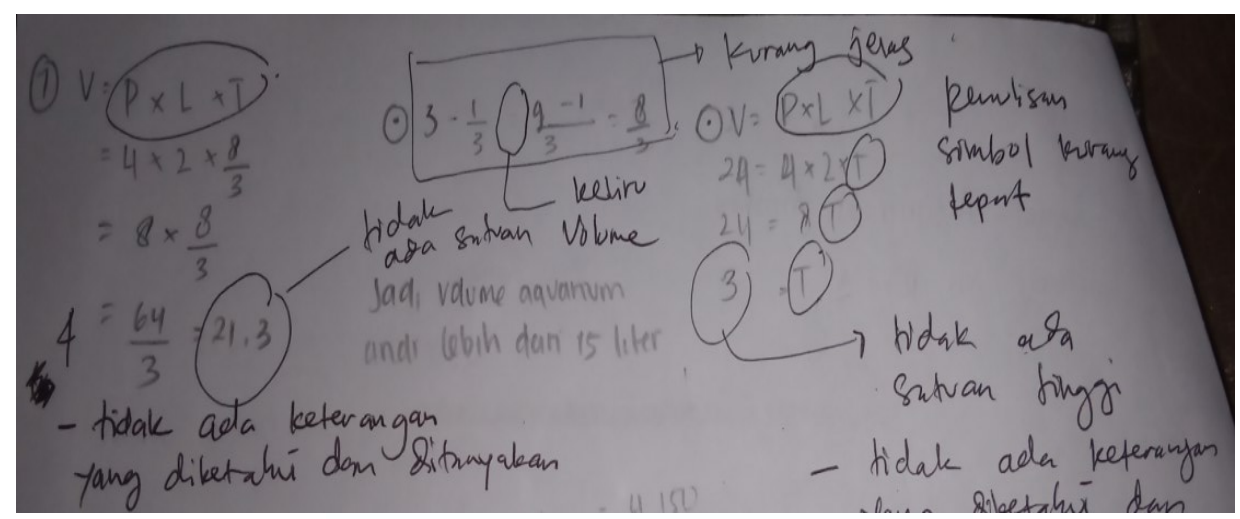

Gambar 1. Kesalahan Jawaban Soal 1

Siswa mencoba menyelesaikan permasalahan pada Nomor 1, terdapat beberapa kesalahan yang dilakukan siswa diantaranya siswa tidak menuliskan keterangan apa saja yang diketahui dan ditanyakan, melakukan operasi pengurangan dengan tanpa memperhatikan sistematis pengerjaannya, tidak adanya satuan pada volume dan tinggi, menggunakan beberapa simbol panjang, lebar dan tinggi menggunakan huruf kapital. Dari analisis tersebut dapat dikatakan bahwa siswa tidak mampu mengiterpretasikan masalah.

\section{Jawaban siswa pada soal Nomor 2}

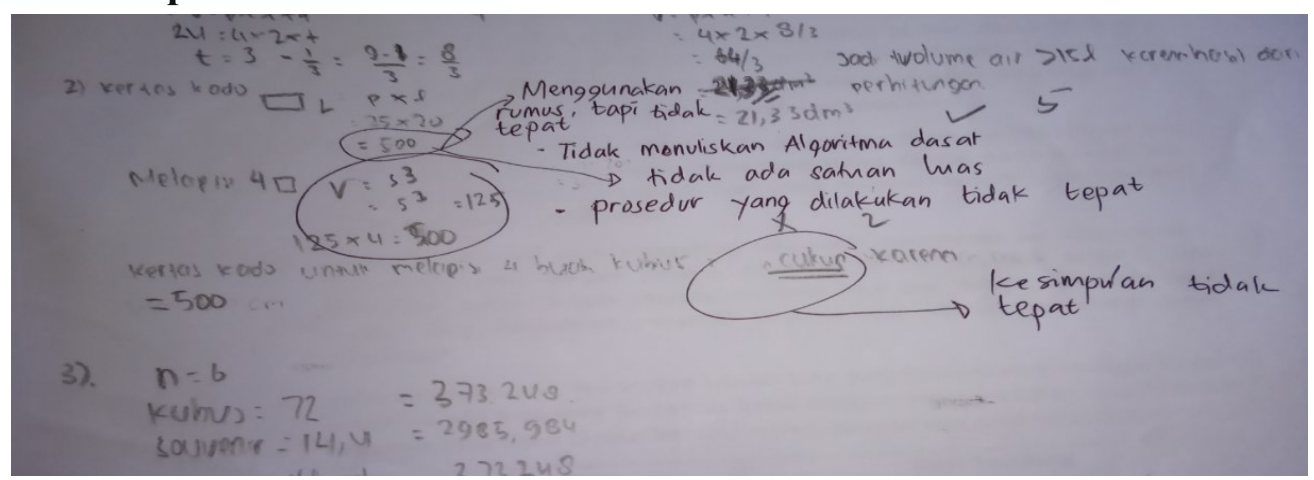

Gambar 2. Kesalahan Jawaban Soal 2 
Pada soal Nomor 2 siswa tidak menuliskan algotima dasar, rumus yang digunakan dalam menyelesaikan masalah tidak tepat, prosedur yang dilakukan siswa tidak tepat sama sekali, sehingga kesimpulan akhir yang diperoleh juga tidak tepat. Dari analisis tersebut dapat disimpulkan bahwa siswa tersebut tidak mampu menginterpretasikan masalah dan menyelesaikannya dengan menggunakan rumus.

\section{Jawaban siswa pada soal Nomor 3}

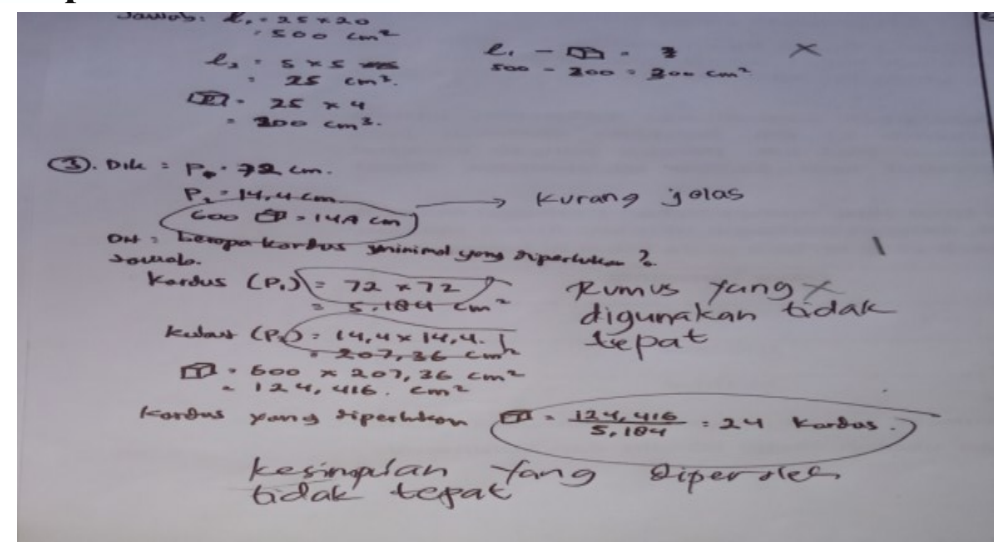

Gambar 3. Kesalahan Jawaban Soal 3

Jawaban siswa pada soal Nomor 3 siswa menuliskan apa yang diketahui dan ditanyakan namun kurang jelas dalam penulisannya, selain itu siswa juga keliru dalam menggunakan rumus, sehingga apa yang dicari tidak ditemukan atau kesimpulan yang diperoleh tidak tepat. Maka dari analisis tersebut dapat dikatakan bahwa siswa tersebut tidak mampu melaksanakan prosedur dengan baik dalam menyelesaikan soal serta tidak dapat memilih strategi pemecahan masalah yang sederhana.

\section{Jawaban siswa pada Nomor 4}

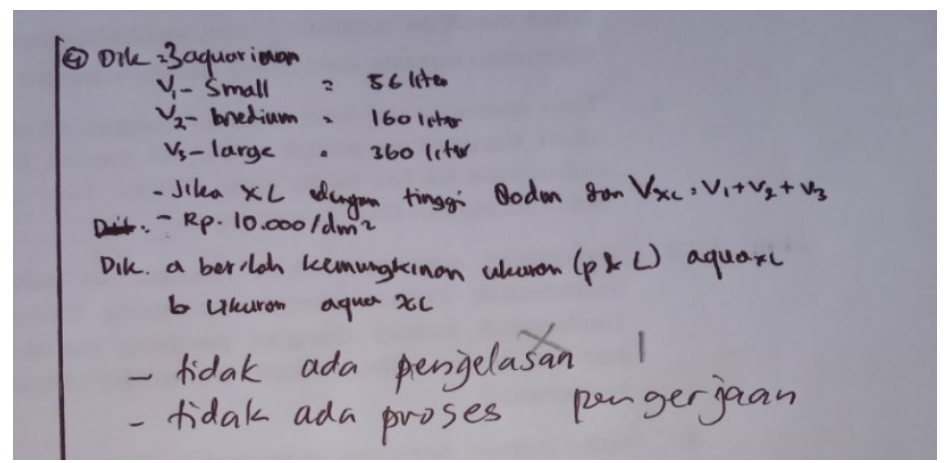

Gambar 4. Kesalahan Jawaban Soal 4

Jawaban siswa pada Nomor 4 hanya mencantumkan apa yang diketahui dan ditanyakan, siswa tidak melakukan proses pengerjaan dan strategi penyelesaian. Sehingga siswa tidak tuntas dalam menyelesaikan soal karena siswa tidak dapat bekerja efektif dengan model dan tidak dapat memilih serta mengintegrasikan representasi yang berbeda, kemudian menghubungkannya dengan dunia nyata.

Dari hasil penelitian memperlihatkan bahwa tingkat kemampuan siswa perlu dilatih kembali dalam menguasai permasalahan dan memberikan solusi dari permasalahan kemampuan literasi, sehingga siswa mampu memberikan solusi serta menganalisis suatu malasah yang dihadapi. Maka diperlukan suatu tindakan untuk mengatasi masalah tersebut, yaitu salah satunya dengan 
pendekatan pembelajaran, hal tersebut seirama dengan pendapat Herdiman (2017), yang mengatakan pendekatan pembelajaran diterapkan dengan tujuan mengaktifkan siswa dalam mengembangkan daya bernalar matematik sehingga siswa mampu mengembangkan dan mengevaluasi suatu argumentasi.

\section{KESIMPULAN}

Selain itu dari total 4 soal literasi yang diberikan diperoleh 58\% siswa mampu menguasai soal literasi matematis, sehingga diperoleh $42 \%$ siswa tidak bisa menguasai soal kemampuan literasi matematis. Rata-rata nilai siswa yaitu 34,29 dengan nilai tertinggi 50 dan nilai terendahnya adalah 16 dari total nilai maksimalnya 55. Berdasarkan apa yang dibahas di atas dapat disimpulkan beberapa kekeliruan yang dilakukan siswa yaitu: (1) Proses penyelesaian yang dilakukan tidak sistematis; (2) salah dalam menggunakan rumus; (3) Banyak yang tidak menggunakan satuan; (4) keliru dalam menuliskan satuan; (5) tidak mampu mengiterpretasikan soal; (6) keliru dalam menyimpulkan hasil penyelesaian; (7) tidak tuntas dalam penyelesaian.

\section{UCAPAN TERIMAKASIH}

Peneliti sangat menyadari pada saat penyusunan artikel ini tidak dapat menyelesaikan tanpa bantuan dari berbagai pihak. Oleh sebab itu, pada kesempatan ini peneliti sangat berterimakasih kepada Kepala Sekolah SMK Negeri 1 Cimahi Drs. Daud Saleh, MM, guru mata pelajaran matematika Endang Rivai, S. Si, seluruh siswa kelas XII Teknik Transmisi A, dan Luvy Sylviana Zanthy, selaku dosen mata kuliah PTK. Atas dukungan beliau, peneliti mampu menyelesaikan penelitian dan penulisan artikel ilmiah ini.

\section{DAFTAR PUSTAKA}

Abdurrahman, M. (1999). Pendidikan Bagi Anak Berkesulitan Belajar. Jakarta: PT. Rineka Cipta

Abdurrahman. (2005). Dasar - Dasar Public Relation. Bandung : PT. Citra Aditya Bakti.

Azia, Y. M. (2004). Upaya Mengatasi Kesulitan Siswa Belajar Geometri dengan Pengajaran Remedial Kelompok dan Remedial Bersama di Sekolah Lanjutan Tingkat Pertama (Http://digilib.upi.edu/pasca/available/etd-1011106-131035/ di akses tanggal 27 April 2019)

Mahdiansyah, \& Rahmawati. (2014) Literasi matematika siswa pendidikan menengah : Analisis menggunakan desain tes internasional dengan konteks Indonesia. Jurnal Pendidikan dan Kebudayaan, 20(4), 452-469.

Maryanti, E. (2012). Peningkatan Literasi Matematis Siswa melalui Pendekatan Metacognitive Guidance. Tesis pada Jurusan Pendidikan Matematika UPI Bandung: tidak diterbitkan.

Nawani, H. (2012). Metode Penelitian Bidang Sosial. Yogyakarta: Gadjah Mada University Press.

OECD. (2016). PISA 2015 results excellence and equity in education (Volume 1). Paris: OECD Publishing.

Poerwadarminta, W. J. S. (2006). Kamus Umum Bahasa Indonesia. Jakarta: Balai Pustaka.

Sahriah. (2012). Analisis Kesalahan Siswa dalam Menyelsaikan Soal Matematika Materi Operasi Pecahan Bentuk Aljabar Kelas VIII SMP Negeri 2 Malang. Jurnal Pendidikan Matematika. 1(1).

Ruswati, D., Utami, W. T., \& Senjayawati, E. (2018). Analisis Kesalahan Siswa SMP dalam Menyelesaikan Soal Kemampuan Pemecahan Masalah Matematis Ditinjau dari Tiga Aspek. MAJU: Jurnal Ilmiah Pendidikan Matematika, 5(1). 